\title{
Calcium release and physical properties of modified carbonate apatite cement as pulp capping agent in dental application
}

\author{
Myrna Nurlatifah Zakaria ${ }^{1}$, Arief Cahyanto $^{2^{*}}$ (D) and Ahmed El-Ghannam ${ }^{3}$
}

\begin{abstract}
Background: Carbonate apatite $\left(\mathrm{CO}_{3} \mathrm{Ap}\right)$ and silica-calcium phosphate composite (SCPC) are bone substitutes with good prospect for dental application. SCPC creates a hydroxyapatite surface layer and stimulate bone cell function while, $\mathrm{CO}_{3} \mathrm{Ap}$ induce apatite crystal formation with good adaptation providing good seal between cement and the bone. Together, these materials will add favorable properties as a pulp capping material to stimulate mineral barrier and maintain pulp vitality. The aim of this study is to investigate modification of $\mathrm{CO}_{3} \mathrm{Ap}$ cement combined with SCPC, later term as $\mathrm{CO}_{3} \mathrm{Ap}-\mathrm{SCPC}$ cement (CAS) in means of its chemical (Calcium release) and physical properties (setting time, DTS and $\mathrm{pH}$ value).

Methods: The study consist of three groups; group 1 (100\% calcium hydroxide, group $2 \mathrm{CO}_{3} \mathrm{Ap}$ (60\% DCPA: 40\% vaterite, and group 3 CAS (60\% DCPA: 20\% vaterite: 20\% SCPC. Distilled water was employed as a solution for group 1, and $0.2 \mathrm{~mol} / \mathrm{L} \mathrm{Na} \mathrm{PO}_{4}$ used for group 2 and group 3 .

Samples were evaluated with respect to important properties for pulp capping application such as $\mathrm{pH}$, setting time, mechanical strength and calcium release evaluation.

Results: The fastest setting time was in $\mathrm{CO}_{3}$ Ap cement group without SCPC, while the addition of 20\% SCPC slightly increase the $\mathrm{pH}$ value but did not improved the cement mechanical strength, however, the mechanical strength of both $\mathrm{CO}_{3} \mathrm{Ap}$ groups were significantly higher than calcium hydroxide. All three groups released calcium ions and had alkaline pH. Highest pH level, as well as calcium released level, was in the control group.

Conclusion: The CAS cement had good mechanical and acceptable chemical properties for pulp capping application compared to calcium hydroxide as a gold standard. However, improvements and in vivo studies are to be carried out with the further development of this material.
\end{abstract}

Keywords: Carbonate apatite, Silica-calcium phosphate composite, $\mathrm{CO}_{3} \mathrm{Ap}-\mathrm{SCPC}$ cement, Pulp capping

\section{Background}

Silica-calcium phosphate composite (SCPC) and carbonate apatite $\left(\mathrm{CO}_{3} \mathrm{Ap}\right)$ are bioceramics material that has been intensively studied for bone repair [1-8]. $\mathrm{CO}_{3} \mathrm{Ap}$ is a full transformed cement with high solubility to be replaced by new bone formation, oscteoclastic bone resorption followed by new bone formation was observed in implanted $\mathrm{CO}_{3} \mathrm{Ap}$ granules in bone defect $[1,9]$. Fabrication of carbonate apatite cement from vaterite and dicalcium phosphate

\footnotetext{
* Correspondence: arief.cahyanto@fkg.unpad.ac.id

${ }^{2}$ Department of Dental Materials Science and Technology, Faculty of

Dentistry, Universitas Padjadjaran, Sumedang-Jatinangor, Indonesia

Full list of author information is available at the end of the article
}

anhydrous (DCPA; $\mathrm{CaHPO}_{4}$ ) powder mixed with various sodium phosphate solutions: $\mathrm{NaH}_{2} \mathrm{PO}_{4}, \mathrm{Na}_{2} \mathrm{HPO}_{4}$, and $\mathrm{Na}_{3} \mathrm{PO}_{4}$ showed that transformation rate of cement to form $\mathrm{CO}_{3} \mathrm{Ap}$ was affected by the solutions $\mathrm{pH}$. Therefore, 0.2 $\mathrm{mol} / \mathrm{L} \mathrm{Na} \mathrm{PO}_{4}$ solution with $\mathrm{pH} 12.3$ for fastest $\mathrm{CO}_{3} \mathrm{Ap}$ transformation rate compared to the others was used in this present study [2]. One of the advantages of $\mathrm{CO}_{3} \mathrm{Ap}$ cement is that it can set in the physiological condition through a dissolution-precipitation reaction. After mixing with $\mathrm{Na}_{3} \mathrm{PO}_{4}$ solution, the vaterite and DCPA dissolved to supply $\mathrm{Ca}^{2+}, \mathrm{PO}_{4}{ }^{3-}$, and $\mathrm{CO}_{32-}$ ions, which play important role in mineralized tissue regeneration as well as in dentinogenesis $[10,11]$. 
SCPC withdrew $\mathrm{Ca}^{2+}$ ions from it surrounding to its surface which provides $\mathrm{Ca}^{2+}$ ions for osteoblast activity, by facilitating osteoblast to differentiate to mature bone-forming cells $[7,12]$. SCPC has been implanted to alveolar bone socket after tooth extraction and after 6 months a bone core was taken for histological evaluation followed by an implant placement. Histomorphometric analysis showed good regeneration of new vital bone and radiographic assessment immediately after extraction compared to 6 months after extraction and grafted by SCPC granules showed a minimum changed in alveolar ridge dimensions [6]. An in vitro study demonstrated that SCPC exhibited a controlled release of silicon and phosphate ions in cell culture media delivering a natural stimulus for bone-cell differentiation $[13,14]$.

The pulp is a loose connective tissue in the central of a tooth, with various cells including fibroblast, odontoblast, immune cells, undifferentiated mesenchymal cells, sensory nerves and blood vessels [15]. It plays a pivotal part in maintaining the vitality of the tooth for regenerative, sensory, and nutritive function. If an injury to the enamel or dentin occurs, the pulp will protect itself by pumping immune cells to injured area, as well as stimulating the odontoblast to form a reparative or reactive dentin in order to block the irritants, preventing harm to reach to the pulp and maintain a vital and healthy pulp with no irreversible pulp inflammation [15-18]. However, the pulp can be injured due to enamel and dentin fracture, or progressive dental caries resulting pulp exposure, causing irreversible inflammation and eventually causing pulp necrosis. This will act as a port of entry for bacteria to colonize the pulp space inducing periapical lesion (periapical abscess, cyst, granuloma), therefore in these kind of situation, root canal treatment will be the only treatment choice besides tooth extraction [16, 17].

Treatment choice for exposed dental pulp to save its vitality is called pulp capping. Pulp capping is a treatment by placing a biocompatible material on the exposed pulp to stimulate the formation of mineralized dentinal bridge or reparative dentin prior the definite restoration. The gold standard material for this purpose is calcium hydroxide $\left[\mathrm{Ca}(\mathrm{OH})_{2}\right]$ which has been used from the early 1920 s, for its biocompatibility and ability to stimulate hard tissue formation as well as antibacterial effect [17]. The liberation of hydroxyl and calcium ions is believed to be the basic mechanism for its high $\mathrm{pH}$ contributing to antibacterial effect and activation of alkaline phosphates (ALP) involved in hard tissue formation [16-20]. Some drawbacks concerning this compound including its high solubility, degradation of material over time, weak dentinal barrier formation, poor adhesion property to tooth structure, and long uncontrolled chronic inflammation to the pulp [19, 21-24].

The tooth and bone, are principally similar in their structure, in which they are mainly composed of hydroxyapatite
$\left[\mathrm{Ca}_{10}\left(\mathrm{PO}_{4}\right)_{6}(\mathrm{OH})_{2}\right]$ crystal, carbonate-substituted as the major part of their inorganic constituent. Pondering the same major component of dentin and bone, we proposed the used of $\mathrm{CO}_{3} \mathrm{Ap}$ and SCPC as novel pulp capping materials that are biocompatible, bioactive and able to set in the physiological environment to induced mineralization over the expose pulp and maintain the pulp vitality. Our previous study has already evaluated the different ratio of $\mathrm{CO}_{3} \mathrm{Ap}$ and SCPC for the best formula for this purpose [22]. The present study is a sequel of previous one, to evaluate the physical properties ( $\mathrm{pH}$, setting time, DTS) and $\mathrm{Ca}^{2+}$ ions release of the new $\mathrm{CO}_{3} \mathrm{Ap}-\mathrm{SCPC}$ cement as new pulp capping material.

\section{Methods}

\section{Preparation of $\mathrm{CO}_{3} \mathrm{Ap}$ and SCPC powders}

The $\mathrm{CO}_{3} \mathrm{Ap}$ powder composed in this study consists of DCPA (J.T. Baker Chemical Co., NJ, USA) and vaterite. The DCPA powder was grinded to reduce the particle size to $0.4 \mu \mathrm{m}$ using a planetary ball mill (Fritsch 86560 , Idar-Oberstein, Germany) with 95\% ethanol for $1 \mathrm{~h}$ and drying for $3 \mathrm{~h}$. The vaterite powder was prepared according to the previous report [25]. In brief, $50 \mathrm{~g}$ of $\mathrm{Ca}(\mathrm{OH})_{2}$ was put into $500 \mathrm{~mL}$ of methanol and $25 \mathrm{~mL}$ of distilled water. The $\mathrm{CO}_{2}$ gas was blown at a rate of $1 \mathrm{~L} / \mathrm{min}$ for $120 \mathrm{~min}$ into the suspension and the temperature was set at $20^{\circ} \mathrm{C}$. The obtained particles were collected and dried at $110^{\circ} \mathrm{C}$. The average particle size of vaterite powder was approximately $0.7 \mu \mathrm{m}$. The SCPC used to modified the $\mathrm{CO}_{3} \mathrm{Ap}$ consists of $19.49 \% \mathrm{SiO}_{2}, 20.34 \% \mathrm{P}_{2} \mathrm{O}_{5}, 40.68 \%$ $\mathrm{CaO}$ and $19.49 \% \mathrm{Na}_{2} \mathrm{O}$ (in mol \%) as it demonstrated favorable physiochemical and bioactivity properties of Si-rich SCPC [13]. The powder metallurgy technique was employed to prepare the SCPC powders. The powders were mixed in polyethylene bottles over a roller for $24 \mathrm{~h}$, then calcinated at $800^{\circ} \mathrm{C}$ (Thermolyne 30,400, Barnstead International, Dubuque, IA) for $1 \mathrm{~h}$, and then ground to the size average of $90-150 \mu \mathrm{m}$.

\section{Preparation of $\mathrm{Ca}(\mathrm{OH})_{2}$ powder}

In this study, a commercial $\mathrm{Ca}(\mathrm{OH})_{2}$ powder (Merck, Darmstadt, Germany) was employed as a control. Sample manipulation was done as the manufacturer instruction.

\section{Preparation of the samples}

The powder cement ratio divided into 3 groups: group 1 $\left(100 \% \mathrm{Ca}(\mathrm{OH})_{2}\right)$ as a control, group 2 (60\% DCPA: $40 \%$ vaterite), and group 3 (60\% DCPA: $20 \%$ vaterite: $20 \%$ SCPC). Distilled water was used as solution for group 1, and $0.2 \mathrm{~mol} / \mathrm{L} \mathrm{Na} \mathrm{PO}_{4}$ used for group 2 and group 3.

\section{Setting time}

All group samples were prepared at liquid-to-powder $(\mathrm{L} / \mathrm{P})$ ratios of 0.5 . Setting time of all samples were 
measured according to the method set in ISO 1566 for dental zinc phosphate cement. In this method, a cement is considered to set when a $400 \mathrm{~g}$ weight loaded onto a Vicat needle with a tip diameter of $1.0 \mathrm{~mm}$ fails to make a perceptible circular indentation on the surface of the cement. The standard requires the cement to be maintained at a temperature of $37^{\circ} \mathrm{C}$ and $100 \%$ relative humidity to simulate the clinical condition. In the present study, the specimen was placed on Teflon mold for setting time measurement. Mean setting time $(n=5)$ was obtained, and the standard deviation was used as an evaluation of standard uncertainty.

\section{$\mathrm{pH}$ measurement}

$\mathrm{pH}$ was observed using $\mathrm{pH}$ meter (pH -207, Lutron Co., Taipei, Taiwan). Before measurement, $\mathrm{pH}$ meter was calibrated by a buffer solution of $\mathrm{pH} 4$ and 7. After calibrated, $\mathrm{pH}$ solution was measured by putting the electrode inside the tube with a sample and deionized water for $0.5,1,24,72$ and $168 \mathrm{~h}$.

\section{Calcium released}

The calcium released was examined using spectrophotometer UV/VIS (Spectronic Camspec Ltd., Leeds, UK). The set cement sample was put into a tube filled with $10 \mathrm{~mL}$ of deionized water at $37^{\circ} \mathrm{C}$. The stored water was measured for $\mathrm{Ca}^{2+}$ ions analysis for $0.5,1,24,72$ and $168 \mathrm{~h}$.

The formula to measure calcium released was below:

$$
\text { Calcium }\left(\frac{m m o l}{-L}\right)=\frac{\text { Abs.Test }}{\text { Abs.Std }} x \text { Standard }
$$

\section{Mechanical strength measurement}

The mechanical strength of the samples was examined in terms of diametral tensile strength (DTS). Each group was mixed with the different aqueous solution, at liquid to powder ratio of 0.5 and set at $37^{\circ} \mathrm{C}$ and $100 \%$ of relative humidity for $72 \mathrm{~h}$. The paste was put into a Teflon mold ( $6 \mathrm{~mm}$ in diameter $\times 3 \mathrm{~mm}$ in height), both ends of the mold were covered with glass slides then clamped. The molds were placed inside a plastic container with distilled water to maintain $100 \%$ relative humidity. The plastic container was placed into an incubator and kept at $37^{\circ} \mathrm{C}$ for $72 \mathrm{~h}$. The samples were removed from the mold after completion of treatment times and immersed in the $99 \%$ ethanol for $3 \mathrm{~min}$ then dried at $80^{\circ} \mathrm{C}$ for $3 \mathrm{~h}$. Then, the samples were crushed using a universal testing machine (LRX Plus; Llyod Instruments, Ltd., West Sussex, UK) with $5.6 \mathrm{kN}$ of preload stress at a crosshead speed of $1 \mathrm{~mm} / \mathrm{min}$. DTS values were taken as the average of at least 5 samples.

\section{Results}

Table 1 summarizes the setting time comparison between $\mathrm{Ca}(\mathrm{OH})_{2}, \mathrm{CO}_{3} \mathrm{Ap}$ and CAS. The $\mathrm{Ca}(\mathrm{OH})_{2}$ was mixed with distilled water as a control, $\mathrm{CO}_{3} \mathrm{Ap}$ and CAS was mixed with $0.2 \mathrm{~mol} / \mathrm{L} \mathrm{Na}_{3} \mathrm{PO}_{4}$, respectively. The setting time of each group were statistically different where the $\mathrm{CO}_{3} \mathrm{Ap}$ group had the fastest setting time $(13.08 \pm 0.05 \mathrm{~min})$ followed by $\mathrm{CAS}$ and $\mathrm{Ca}(\mathrm{OH})_{2}$.

The mean $\mathrm{pH}$ value and standard deviations recorded for three different material group at the various period of time are plotted in Fig. 1. In this study, calibration of $\mathrm{pH}$ was conducted using buffer solution before $\mathrm{pH}$ measurement and were similar as buffer control. The $\mathrm{Ca}(\mathrm{OH})_{2}$ revealed higher $\mathrm{pH}$ values than other samples at all period of time evaluation $(p<0.05)$. The $\mathrm{pH}$ values of $\mathrm{CO}_{3} \mathrm{Ap}$ and CAS were similar to each other and the $\mathrm{pH}$ values in these both groups gradually decreased until near neutral at $168 \mathrm{~h}$.

Figure 2 presents the mean $\mathrm{Ca}^{2+}$ ions released and standard deviations provided by three different materials as a function of time. The $\mathrm{Ca}(\mathrm{OH})_{2}$ released $0.81 \mathrm{mmol} / \mathrm{L} \mathrm{Ca}^{2+}$ ions in the first $0.5 \mathrm{~h}$ and increased significantly to 125.20 $\mathrm{mmol} / \mathrm{L}$ at $168 \mathrm{~h}$. The $\mathrm{Ca}^{2+}$ ions released for $\mathrm{CO}_{3} \mathrm{Ap}$ group showed stable results in all the period of time. While, CAS had higher $\mathrm{Ca}^{2+}$ ions released in the first $0.5 \mathrm{~h}$ $(1.84 \mathrm{mmol} / \mathrm{L})$. However, the $\mathrm{Ca}^{2+}$ ions released on CAS group gradually decreased until $0.01 \mathrm{mmol} / \mathrm{L}$ at $24 \mathrm{~h}$.

Figure 3 shows the mean of DTS values of three different materials after setting at $37{ }^{\circ} \mathrm{C}, 100 \%$ relative humidity for $72 \mathrm{~h}$. The mean DTS values of $\mathrm{CO}_{3} \mathrm{Ap}(4.16 \pm 1.36 \mathrm{MPa})$ and CAS $(3.92 \pm 1.07 \mathrm{MPa})$ were statistically higher than $\mathrm{Ca}(\mathrm{OH})_{2}(0.21 \pm 0.47 \mathrm{MPa})$. However, there was no statistical significance on DTS values between $\mathrm{CO}_{3} \mathrm{Ap}$ and CAS.

\section{Discussion}

The setting of the $\mathrm{CO}_{3} \mathrm{Ap}$ cement lies on dissolution-precipitation reaction. After mixing with 0.2 $\mathrm{mol} / \mathrm{L} \mathrm{Na}_{3} \mathrm{PO}_{4}$ solution, the powder will dissolve and supply $\mathrm{Ca}^{2+}, \mathrm{PO}_{4}{ }^{3-}$ and $\mathrm{CO}_{3}{ }^{2-}$ ions. As the solution gets supersaturated, precipitation occurs and forms $\mathrm{CO}_{3} \mathrm{Ap}$ crystals and the cement will set $[1,9,10]$. As shown in Table 1 the setting time for $\mathrm{CO}_{3} \mathrm{Ap}$ cement without the addition of SCPC is significantly higher than $\mathrm{CO}_{3} \mathrm{Ap}$ and $\mathrm{Ca}(\mathrm{OH})_{2}$ cement. The $\mathrm{CO}_{3} \mathrm{Ap}$ cement consists of higher percentage

Table 1 Comparison of calcium hydroxide, carbonate apatite and carbonate apatite-SCPC on setting time evaluation ( $n=5)$

\begin{tabular}{lll}
\hline Liquid & Powder & $\begin{array}{l}\text { Setting time (minutes) } \\
\text { L/P } 0.5\end{array}$ \\
\hline Distilled water & Calcium hydroxide & $38.05 \pm 0.12$ \\
$\mathrm{Na}_{3} \mathrm{PO}_{4}$ & Carbonate apatite $^{*}$ & $13.08 \pm 0.05$ \\
& Carbonate apatite-SCPC $^{* *}$ & $26.93 \pm 0.21$ \\
\hline
\end{tabular}

$n=5 ;{ }^{* * * *} p<0.05$ 


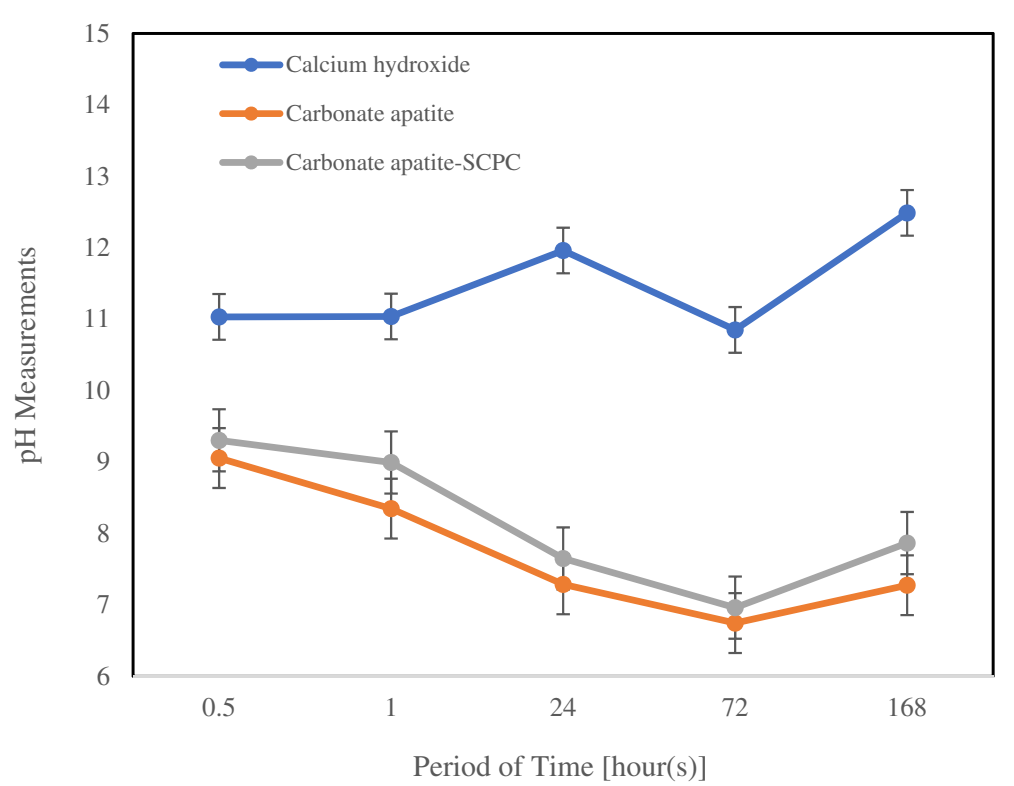

Fig. $1 \mathrm{pH}$ values for three different materials in various period of time. At least 5 samples were measured for $\mathrm{pH}$. Errors bars indicate the standard deviation

of vaterite that has high solubility thus enabling precipitation of $\mathrm{CO}_{3} \mathrm{Ap}$ in a shorter time. This was also one of the reasons for employing vaterite instead of calcite in this study. On the other hand, SCPC added in group 3 were in the form of granules that do not dissolve in short time, they do release $\mathrm{Ca}, \mathrm{P}, \mathrm{Na}$, and $\mathrm{Si}$ ions but they do not have the ability to set. ${ }^{8}$ This was also the reason why we combine the SCPC with $\mathrm{CO}_{3} \mathrm{Ap}$ instead of using pure SCPC for pulp capping purpose.

To achieve a favourable cement to be applied as pulp capping agent, adequate setting time and the ability to set in a moist environment with the presence of blood

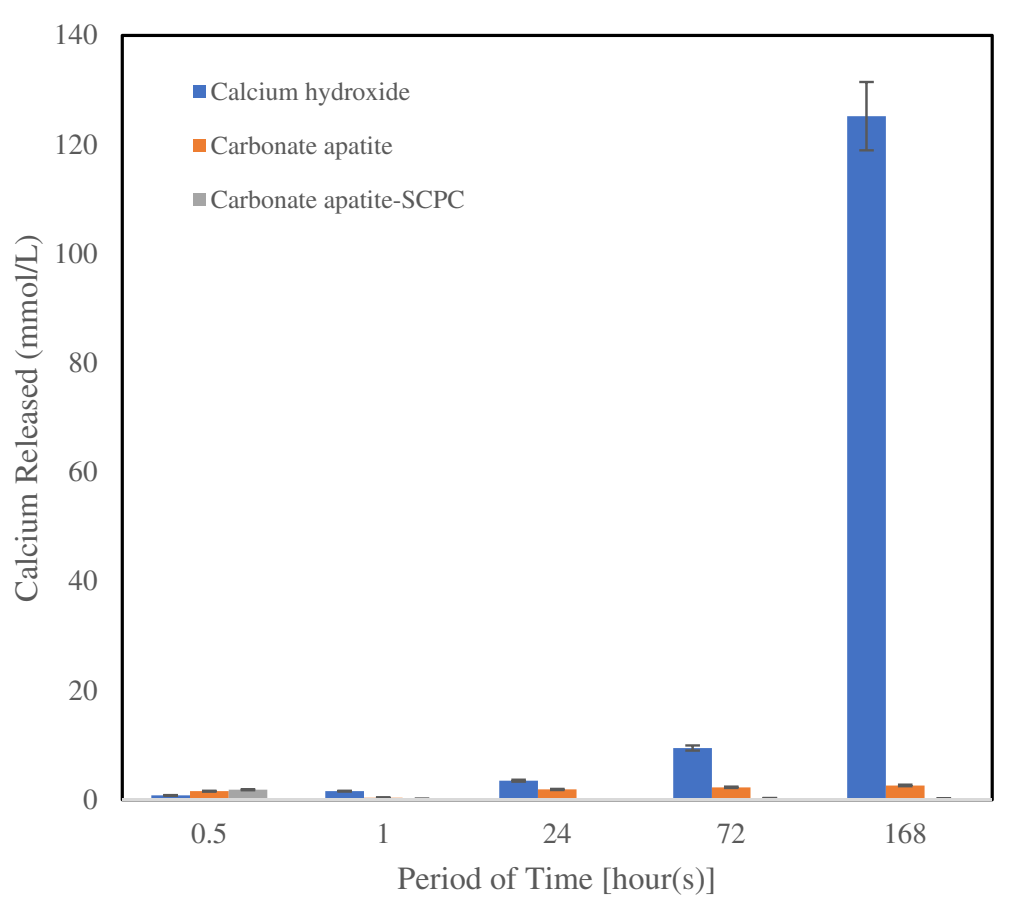

Fig. 2 The concentration of Calcium released from the set of three different materials. At least 5 samples were measured for calcium released. Errors bars indicate the standard deviation 


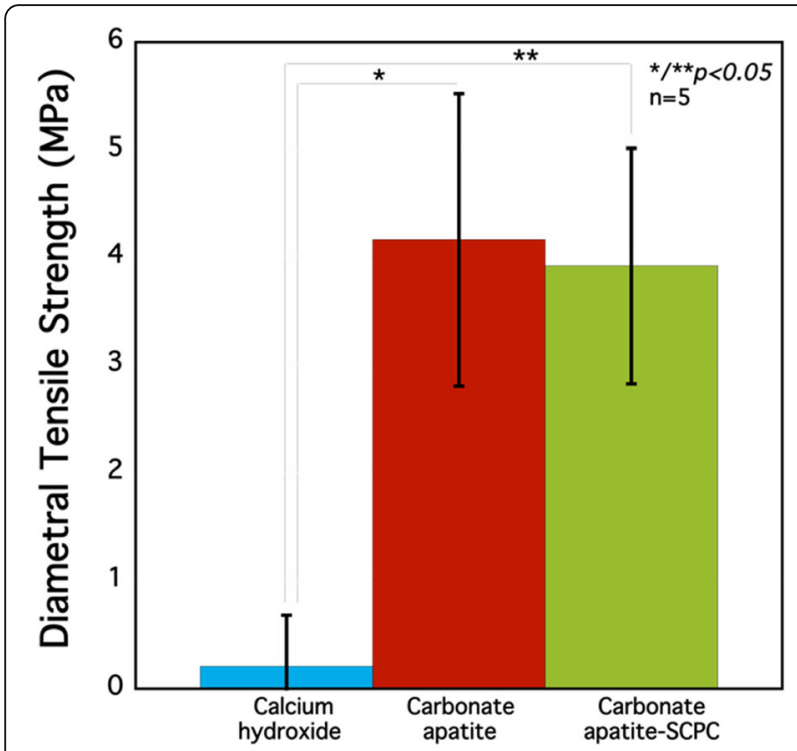

Fig. 3 Diametral tensile strength values of the set three different materials after $72 \mathrm{~h}$. At least 5 samples were measured for DTS evaluation. Errors bars indicate the standard deviation

or blood clot will give the best result, because the material will hold place without being washed out. This is one of $\mathrm{Ca}(\mathrm{OH})_{2}$ drawback, because it is easy to get dissolved and have a poor adhesive ability to tooth structure. An ideal pulp capping material should have the ability to adapt and adhere to the tooth structure, providing tight seal to prevent microleakage and bacterial penetration $[17,26]$.

The longest setting time for $\mathrm{Ca}(\mathrm{OH})_{2}$ relates on the high solubility and could also relate to its larger particle size $(37 \mu \mathrm{m})$, compared to DCPA $(0.3-0.5 \mu \mathrm{m})$ and vaterite $(0.6-0.9 \mu \mathrm{m})$. The $\mathrm{Ca}(\mathrm{OH})_{2}$ setting mechanism is based on acid-base reaction between $\mathrm{Ca}(\mathrm{OH})_{2}$ and 1-methyl trimethylene disalicylate, forming an amorphous calcium-disalicylate salt, with $\mathrm{Ca}^{2+}$ ions intercalated with disalicylate molecules. For faster setting time, commercially $\mathrm{Ca}(\mathrm{OH})_{2}$ products added accelerator in the form base and catalyst paste, enabling more predictable and faster setting time, however, this approach did not solve the adhesive problem. Meanwhile, the addition of SCPC to $\mathrm{CO}_{3} \mathrm{Ap}$ cement slightly decreased the mechanical strength with no significant difference. In line with our previous study, the addition of 10 and $20 \%$ of SCPC did not gave significant difference and had better mechanical strength compared to 10 and 40\% addition of SCPC. The bioactive silicate functional groups of SCPC appeared to bind the $\mathrm{CO}_{3} \mathrm{Ap}$ components in the CAS cement and formed a more compact and dense structure as seen in the SEM analyses [22].

The $\mathrm{pH}$ evaluation showed a trend of $\mathrm{pH}$ value that slowly decreases over time in both $\mathrm{CO}_{3} \mathrm{Ap}$ cement group with or without $\mathrm{SCPC}$, whereas $\mathrm{Ca}(\mathrm{OH})_{2}$ have a relatively stable $\mathrm{pH}$ level until $168 \mathrm{~h}$ observation. This showed that, after precipitation and the formation of the $\mathrm{CO}_{3} \mathrm{Ap}$ crystal, $\mathrm{pH}$ decreases, though did slightly elevate at $168 \mathrm{~h}$ evaluation and tend to be at neutral level. However, the addition of SCPC to $\mathrm{CO}_{3} \mathrm{Ap}$ cement did not gave any significant effect on the $\mathrm{pH}$ level. This is completely different compared to the $\mathrm{Ca}(\mathrm{OH})_{2}$ group that still have relatively high $\mathrm{pH}$ level (above 11) for all evaluation time. The relatively high $\mathrm{pH}$ for $\mathrm{Ca}(\mathrm{OH})_{2}$ group are closely related to the dissolution of $\mathrm{Ca}^{2+}$ and $\mathrm{OH}^{-}$ ions after the powder was manipulated with distilled water. Alkaline $\mathrm{pH}$ of the dental material is strongly associated with its antimicrobial effect because the alkaline environment will interfere bacterial proliferation [17, 26-28]. Alkaline pH also contribute to the increase expression of bone morphogenetic protein-2 (BMP-2), alkaline phosphatase (ALP), and promotes the formation of calcified nodules favoring the tissue environment to stimulate the healing process [18, 25, 27].

$\mathrm{Ca}^{2+}$ ions also play an important role in the formation of the dentinal bridge. $\mathrm{Ca}^{2+}$ ions stimulate the recruitment and proliferation of undifferentiated cells from the pulp and activate stem cells and odontoblast to form reparative dentin or dentinal bridge to protect an exposed pulp [27, 29]. Moreover, it enhances pyrophosphatase activity, sustaining dentin mineralization and dentinal bridge formation [30]. The bioactivity of a material is affected by the nature structure and surface of the material responsible for water sorption, material solubility and its permeability water diffusion (i.e., porosity) [27]. As expected, the significant difference was observed between the $\mathrm{CO}_{3} \mathrm{Ap}$ and CAS cement to $\mathrm{Ca}(\mathrm{OH})_{2}$ cement that rapidly dissolves. The high solubility of $\mathrm{Ca}(\mathrm{OH})_{2}$ make less effective for application in the presence of blood which typically occurs in exposed pulp, especially in heavily inflamed ones. In general, slow release bioactivity is beneficial to have a balance between material resorption to regeneration, this would probably be hard to achieve in $\mathrm{Ca}(\mathrm{OH})_{2}$ and could be the reason for its weak and tunnel defects on their dentinal bridge formation. However, over stabilization can also result in pointless ionic dissolution.

\section{Conclusion}

Based on our findings of acceptable setting time, alkaline $\mathrm{pH}$ and calcium release, together with previous study on its ability to form reparative dentin in animal study, the novel CAS cement can be considered as a good candidate for pulp capping treatment. Nevertheless, further evaluation on improving the properties still awaits.

\section{Acknowledgments}

The authors grateful of the services and facilities of the Integrated Laboratory of Faculty of Dentistry, Universitas Padjadjaran, Indonesia, and in

collaborative research with the University of North Carolina at Charlotte, USA. 


\section{Funding}

This study was supported by the research grant from LPPM and Faculty of Medicine, Program Study of Dentistry, Universitas Jenderal Achmad Yani, Indonesia No. 225/UNJANI/XI/2015.

\section{Availability of data and materials}

Not applicable.

\section{Authors' contributions}

MNZ performed the setting time, $\mathrm{pH}$, calcium released and was a major contributor in writing the manuscript, AC performed the diametral tensile strength evaluation and analyzed all the results data. AE has synthesized the SCPC powder which used in this study. All authors read and approved the final manuscript

\section{Ethics approval and consent to participate} Not applicable.

\section{Consent for publication}

Not applicable.

\section{Competing interests}

The authors declare that they have no competing interests.

\section{Publisher's Note}

Springer Nature remains neutral with regard to jurisdictional claims in published maps and institutional affiliations.

\section{Author details}

${ }^{1}$ Department of Endodontology and Operative Dentistry, Program Study of Dentistry, Faculty of Medicine, Universitas Jenderal Achmad Yani, Cimahi, Indonesia. ${ }^{2}$ Department of Dental Materials Science and Technology, Faculty of Dentistry, Universitas Padjadjaran, Sumedang-Jatinangor, Indonesia. ${ }^{3}$ Department of Mechanical Engineering and Engineering Science, The University of North Carolina at Charlotte, Charlotte, NC, USA.

Received: 22 June 2018 Accepted: 27 September 2018

Published online: 06 December 2018

\section{References}

1. Ishikawa K. Bone substitute fabrication based on dissolution-precipitation reactions. Materials. 2010;3:1138-55.

2. Cahyanto A, Maruta M, Tsuru K, Matsuya S, Ishikawa K. Fabrication of bone cement that fully transform to carbonate apatite. Dent Mat J. 2015;34(3): 394-401.

3. Cahyanto A, Tsuru K, Ishikawa K. Carbonate apatite formation during the setting reaction of apatite cement. Advances in bioceramics and porous ceramics V. Ceram Eng Sci Proc. 2013:33(6):7-10.

4. Cahyanto A, Tsuru K, Ishikawa K. Transformation of apatite cement to B-type carbonate apatite using different atmosphere. Key Eng Mater. 2016:696:9-13.

5. Cahyanto A, Toita R, Tsuru K, Ishikawa K. Effect of particle size on carbonate apatite cement properties consisting of calcite (or vaterite) and dicalcium phosphate anhydrous. Key Eng Mater. 2014;631:128-33.

6. Al-Sabbagh M, Burt J, Barakat A, Kutkut A, El-Ghannam A. Alveolar ridge preservation using resorbable bioactive ceramic composite: a histological study. J Int Acad Perio. 2013;15(3):91-8.

7. Aniket YA, Marriott I, El-Ghannam A. Promotion of pro-osteogenic responses by a bioactive ceramic coating. J Biomed Mater Res A. 2012;100A:3314-25.

8. El-Ghannam A, Hart A, White D, Cunningham L. Mechanical properties and cytotoxicity of a resorbable bioactive implant prepared by rapid prototyping technique. J Biomed Mater Res Part A. 2013;101A:2851-61.

9. Ishikawa K, Matsuya S. Bioceramics. In: Milne I, Ritchie RO, Karihaloo B, editors. Comprehensive structural integrity, vol 9 Oxford Elsevier: 2003 p. 169-214.

10. Cahyanto A, Maruta M, Tsuru K, Matsuya S, Ishikawa K. Basic properties of carbonate apatite cement consisting of vaterite and dicalcium phosphate anhydrous. Key Eng Mater. 2013;529-530:192-6.

11. Leewenburgh S, Layrolle P, Barrère F, de Bruijn J, Schoonman J, van Blitterswijk CA, de Groot K. Osteoclastic resorption of biomimetic calcium phosphate coatings in vitro. J Biomed Mater Res. 2001;56:208-15.

12. Maeno S, Niki $Y$, Matsumoto $H$, Morioka H, Yatabe $T$, Funayama A, Toyama $Y$, Taguchi T, Tanaka J. The effect of calcium ion con- centration on osteoblast viability, proliferation and differentiation in monolayer and 3D culture. Biomaterials. 2005:26:4847-55.

13. Gupta G, Kirakodu S, El-Ghannam A. Effect of exogenous phosphorus and silicon on osteoblast differentiation at the interface with bioactive ceramics. J Biomed Mater Res A. 2010:95A:882-90.

14. Gupta G, El-Ghannam A, Kirakodu S, Khraisheh M, Zbib H. Enhancement of osteoblast gene expression by mechanically compatible porous Si-rich nanocomposite. J Biomed Mater Res B Appl Biomater. 2007;81:387-96.

15. Boskey AL, Roy R. Cell culture systems for studies of bone and tooth mineralization. Chem Rev. 2008;108(11):4716-33.

16. Fouad AF, Levin L. Pulpal Reactions to Caries and Dental Procedures. In: Hargreaves KM, Cohen S, editors. Cohen's Pathways of The Pulp. 11th ed. Missouri: Mosby Elsevier; 2015. p. 504.

17. Hilton TJ. Key to success with pulp capping: a review of the literature. Oper Dent. 2009:34(5):615-25.

18. Dhillon H, Kaushik M, Sharma R. Regenerative endodontics_creating new horizons. J Biomed Mater Res Part B. 2016;104B:676-85.

19. Cox CF, Subay RK, Ostro E, Suzuki SH. Tunnel defects in dentin bridges their formation following direct pulp capping. Oper Dent. 1996;21:4-11.

20. Gandolfi MG, Siboni F, Botero T, Bossu M, Riccitiello F, Prati C. Calcium silicate and calcium hydroxide materials for pulp capping: biointeractivity, porosity, solubility and bioactivity of current formulations. J Appl Biomater Funct Mater. 2015;13(1):43-60.

21. Parolia A, Kundabala M, Rao NN, Acharya SR, Agrawal P, Mohan M, Thomas M. A comparative histological analysis of human pulp following direct pulp capping with Propolis, mineral trioxide aggregate and Dycal. Aust Dent J. 2010;55:59-64.

22. Zakaria MN, Cahyanto A, El-Ghannam A. Basic properties of novel bioactive cement based on silica-calcium phosphate composite and carbonate apatite. Key Eng Mater. 2017;720:147-52.

23. Zakaria MN, Pauziah NFN, Sabirin IP, Cahyanto A. Evaluation of carbonate apatite in inducing formation of reparative dentin in exposed dental pulp. Key Eng Mater. 2017;758:250-4.

24. Cahyanto A, Rezano A, Zakaria MN, El-Ghannam A. Synthesis and characterization of a novel SCPC-CO $\mathrm{AP}$ cement for pulp capping application in dentistry. Key Eng Mater. 2017;758:29-33.

25. Maeda H, Maquet $V$, Chen QZ, Kasuga $T$, Jawad H, Boccaccini AR. Bioactive coatings by vaterite deposition on polymer substrates of different composition and morphology. Mat Sci Eng C. 2007;27:741-5.

26. Zakaria MN. Save the pulp is the essential issues on pulp capping treatment. J Dentomaxillofac Sci. 2016;1(2):301-5.

27. Poggio C, Lombardini M, Colombo M, Beltrami R, Rindi S. Solubility and pH of direct pulp capping materials: a comparative study. J Appl Biomater Funct Mater. 2015:13(2):181-5.

28. Liu L, Pushalkar S, Saxena D, LeGeros RZ, Zhang Y. Antibacterial property expressed by a novel calcium phosphate glass. J Biomed Mater Res B Appl Biomater. 2014;102(3):423-9.

29. Goldberg M, Smith AJ. Cells and extracellular matrices of dentin and pulp: a biological basis for repair and tissue engineering. Crit Rev Oral Biol Med. 2004;15(1):13-27.

30. Estrela C, Holland R. Calcium hydroxide: study based on scientific evidences. J Appl Oral Sci. 2003;11(4):269-82.

Ready to submit your research? Choose BMC and benefit from:

- fast, convenient online submission

- thorough peer review by experienced researchers in your field

- rapid publication on acceptance

- support for research data, including large and complex data types

- gold Open Access which fosters wider collaboration and increased citations

- maximum visibility for your research: over $100 \mathrm{M}$ website views per year

At BMC, research is always in progress.

Learn more biomedcentral.com/submission 